from two to four weeks after the administration of a dose of a slightly under-neutralized toxin-antitoxin mixture. A sublethal dose of a freshly prepared toxin or of the saline extract described by the author does not produce paralysis in the guinea pig, but a mixture of the two products which permits the survival of the animal for three or four weeks apparently gives rise with constancy to paralytic symptoms.

Evidence is brought forward by the author that certain complex relations between diphtheria toxin and antitoxin when mixtures of them are injected into guinea pigs can be explained on the assumptions : (1) that diphtheria toxins consist of varying proportions of substance $A$ (the toxic component which is characteristic of the P.W. 8 strain) and of substance $B$ (the active constituent of the saline extract) ; and (2) the formation of an antibody to each of these substances.

The author suggests that substance $B$ is of the nature of a diffusing factor, that is, an agent which can be shown experimentally to increase the permeability of the connective tissues to fluids injected into them. He regards as a reasonable hypothesis that the diffusing factor is an integral part of diphtheria toxin, and that, indeed, toxins with similar physical characteristics that are formed by other bacteria consist, in general, of at least two factors, one of which actively promotes the absorption of the others by increasing the permeability of the tissues. An account of biochemical work on the diffusing substance and its probable relationship to mucinase is given in short articles that have recently appeared ${ }^{3}$.

The author indicates the possibility that his results may be applicable to the prophylaxis of diphtheria by modifying the specific products which induce an active immunity to the disease; the immunizing agents now in use are derived from the toxin of the $P . W .8$ strain, and are therefore deficient in substance $B$.

These observations and the inferences drawn from them are regarded by the author as providing the key to a number of difficult problems in the clinical and experimental study of diphtheria. For this reason serologists in laboratories elsewhere will doubtless repeat the work in order to test its validity. The details of results which may have been obtained from therapeutic trials in children with antitoxic sera that have been prepared in accordance with the author's views will be awaited with particular interest.

\footnotetext{
1 Anderson, J. S., Happold, F. C., McLeod, J. W., and Thomson, J. G., J. Path, and Bact., 34, 667-681 (1931).

' O'Meara, R. A. Q., J. Path. and Bact., 51, 317-335 (1940).

${ }^{3}$ Chain, E., and Duthie, E. S., NATURE, 144, 977 (1939) ; Favilli, G., NATURE, 145, 866 (1940); McClean, D., and Hale, C.' W., NATURE, 145, 869 (1940)
}

\title{
CONFERENCE ON INDUSTRIAL RADIOGRAPHY
}

\begin{abstract}
A CONFERENCE on Industrial Radiography organized by the Institute of Physies was held on January 25 in the library of the Research Laboratories of the General Electric Company, by the courtesy of the director, Dr. C. C. Paterson. Dr. V. E. Pullin, radiological consultant to the Aeronautical Inspection Department, was in the chair. The Conference was very well attended; members were present from all parts of Great Britain. They represented the many diverse industries which are now making considerable use of this comparatively new method of engineering inspection and development.
\end{abstract}

The proceedings opened with some introductory observations by the chairman, who emphasized the rapidly growing importance and value of this particular branch of applied science and the great practical advantages which must follow a general discussion of the subject such as the present meeting promised.

The first paper, on the "Application of Radiography to the Electrical Industry", was read by Mr. H. P. Rooksby and Miss K. L. Jackman, both of the Research Department of the General Electric Company. After outlining the general principles and technique underlying the work, the authors described, by the aid of many beautiful radiographs, a number of very interesting applications of this method of investigation. Considerable use has been made of the special technique known as planar radiography, which has already proved of great value in the medical radiographic field. This method has unique advantages where it is desirable to investigate any particular plane of the subject under examination. One of the most interesting applications illustrated by the authors was concerned with the radiography of large water- and air-cooled anode valves. Ordinarily it is an extremely difficult matter to check the final assembly of such apparatus as this, where many critical components are hidden. Even by radiography, the technique is extremely difficult, and very great credit is due to the authors for the beautiful results they have obtained. By means of these pictures the whole electrode assembly can be examined at any stage during manufacture or in the subsequent life of the valve.

The authors stated that in many instances every single valve is subjected to radiographic examination before acceptance. By a method of composite radiography it is possible to deal with valves as much as four feet in height.

Another interesting example is the use of $\mathrm{X}$-rays in detecting defects in the cores of are-lamp carbons. Radiography is used to determine the uniformity in thickness of the glass walls of cathode ray tubes. Radiography by means of the gamma rays of radium is also extensively used by the authors, who have found many useful applications for the method where X-rays are contra-indicated for one reason or another.

In the second paper, Mr. W. L. Harper, of the Aeronautical Inspection Department, Ministry of Aircraft Production, described in some detail the methods adopted in the radiological examination of the light alloy castings used in aircraft construction. The author pointed out that he is principally concerned 
with inspection processes, and remarked that radiological examination is now compulsory in the case of certain important components of aircraft. Many thousands of light alloy castings are inspected by radiological methods every week.

Mr. Harper laid down certain rules which should govern the radiography of light alloys, and explained how radiographic technique has to be modified to yield the best results in different types of alloys. In some cases, fluoroscopic methods are used in the examination of certain castings, and the author remarked on the importance of suitable apparatus for this purpose, which must embody maximum sensitivity with complete safety for the operator; in this connexion, it was pointed out that the fluorescent screen should never be viewed directly but indirectly by means of an inclined mirror. A very large number of firms throughout Great Britain have now installed X-ray equipment and employ trained radiological operators in this work. He contrasted this state of affairs with that obtaining but a few vears ago, when the radiological method was yet in its infancy and its potentialities were largely unrecognized.

In the very encouraging and stimulating third paper, Dr. L. Mullins, of the Research Department of Messrs. Kodak, Ltd., described some of the latest research work carried out in the Kodak Research Laboratories on the photographic materials specially adapted to the needs of industrial and engineering, as apart from medical, radiology. Dr. Mullins first dealt with these specialized requirements and explained how particular emulsions are being devised to meet the needs of the radiologist specializing either in heavy engineering work, or in the examination of light alloys and built-up articles, also in the realm of crystal analysis. He went on to explain some of the technical difficulties inherent in this highly differentiated research, and to describe the methods that are being developed to overcome them. In the final section of his paper he dealt with the general question of processing, and was able to give the meeting some useful advice on this highly im. portant aspect of the work.

To most of those present, it was very gratifying indeed to know that the question of photographic research directed to the particular problems of industrial radiology is being so intensively studied. This development was evident from the comprehensive and careful outline which was presented by Dr. Mullins.

Mr. E. J. Tunnicliffe showed a slide of a piece of apparatus designed by him to facilitate the continuous movement of a specimen under fluoroscopic X-ray examination. A sphere of aluminium, which contains the specimen, is made to rotate in any desired manner in a beam of X-rays ; the fluoroscopic image is thrown on to an inclined mirror and is observed in perfect safety by the operator. The whole operation is one of remote control and combines perfect safety with a high degree of sensitivity and efficiency.

The papers provoked a lively discussion in which the authors were kept busy in answering a diversity of questions. It was evident that the Conference had achieved its object in affording practical help to those engaged on this work and, at the same time, many questions were raised that will undoubtedly stimulate further research and experiment.

V. E. P

\section{FORTHCOMING EVENTS}

[Meeting marked with an asterisk is open to the public.]

\section{Monday, February to}

Royal Geographical Society (at Kensington Gote, London, S.W.7), at 3 p.m.-Prof. F. Debenham : "A Laboratory for Physical Geography".

\section{Tuesday, February II}

Illuminating Engrneering Society (at the E.L.M.A. Lighting Service Bureau, 2 Savoy Hill, London, W.C.2), at 2.30 p.m.-Mr. J. G. Holmes: "The Recognition of Coloured Light Signals".

Royal Institution (at 21 Albemarle Street, London, W.1), at 2.30 p.m.-Prof. G. I. Finch, F.R.S. : "Explosives".*

WARBURG INSTITUTE (at the Imperial Institute Buildings, South Kensington, London, S.W.7), at 2.30 p.m.Dr. F. Saxl: "Mithras-The History of an IndoEuropean Divinity".

\section{Wednesday, February 12}

Royal Society of Arts (at John Adam Street, Adelphi, London, W.C.2), at 1.45 p.m.--Mr. G. V. Jacks: "Humus and the Farmer".

Physrcal Society (Colour Group) (at the Polytechnic, Regent Street, London, W.1), at 2.0 p.m.-Four Papers on "Colour Tolerance" (1, "Introductory"; 2, "The Commercial Aspect"; 3, "The Technical Aspect"; 4, "The Physical Aspect").

\section{Thursday, February 13}

Royal College of Surgeons of England (at the Royal Society of Medicine, I Wimpole Street, London, W.1), at 2.30 p.m.--Prof. A. H. Burgess : The Hunterian Oration.

\section{Friday, February 14}

Association of Applied Brologists (in the Congregational Hall, Victoria Road, Harpenden), at 12 noon. -Annual General Meeting. 12.30 p.m.-Dr. J. Macleod : "Recent Work on the Sheep Tick and its Bearing on Control Measures". 2.15 p.m.-Dr. R. P. Hobson: "Recent Work on the Sheep Maggot Problem"; Dr. I. Thomas: "Some Practical Aspects of the Sheep Blowfly Problem".

Royal Society of Arts (Indta and Burma Section) (at John Adam Street, Adelphi, London, W.C.2), at 1.45 p.m.-Diwan Bahadur S. E. Runganadhan: "Research Work in Indian Universities".

North-EAst Coast Institution of Engineers and ShrpburldDers (in the Mining Institute, Newcastleupon-Tyne), at 6 p.m.-Mr. Leslie T. Morton: "Ships" Cargo-Handling Gear".

\section{APPOINTMENTS VACANT}

Appiolcatrons are invited for the following appointments on or before the dates mentioned:

LECTURER IN Electrical ENGINEERING at the Constantine Tech nical College-The Director of Education, Education Offices, Wood lands Road, Middlesbrough (February 15).

assistant Lecturer in the DePartment of Mathematics-The Principal, Technical College, Huddersfleld (February 20).

DEMONSTRATOR IN THE DEPARTMENT OF PHYSIOLOGY - The Secretary, Bedford College for Women, Regent's Park, London, N.W. (February 22).

HEADMASTER of THE KING's School, ElY-The Bursar, The King's School, Ely, Cambs. (March 1).

Chie EDdCATION OFFIOER to the Portsmouth Education Com. mittee-The Chief Clerk, Education Offlces, Northern Secondary School, Mayfield Road, North End, Portsmouth (March 3).

LECTURER AND/OR INSTRUCTOR IN RADIO ENGINEERING AND SERVICING-The Director of Education, The Polytechnic, 309 Regent Street, London, W.1.

EDdCATION OFFICER-The Acting Secretary, Educational Advisory Board of the British Social Hygiene Council, Tavistock House South, Tavistock Square, London, W.C.1.

Electrical ENGINeER for the Public Works Department of the Government of Nigeria-The Crown Agents for the Colonies, 4 MillGovernment of Nigeria-The Crown Age
bank, London, S.W.1 (quoting M/9422). 